\title{
Response of Amaranthus cruentus cv Mexicano to nitrogen fertilization under irrigation in the temperate, semiarid climate of North Patagonia, Argentina
}

\author{
María Fany Zubillaga, Ricardo Camina, Gustavo Adolfo Orioli \& Daniel \\ Alejandro Barrio
}

To cite this article: María Fany Zubillaga, Ricardo Camina, Gustavo Adolfo Orioli \& Daniel Alejandro Barrio (2019) Response of Amaranthus cruentus cv Mexicano to nitrogen fertilization under irrigation in the temperate, semiarid climate of North Patagonia, Argentina, Journal of Plant Nutrition, 42:2, 99-110, DOI: 10.1080/01904167.2018.1549674

To link to this article: https://doi.org/10.1080/01904167.2018.1549674

曲 Published online: 30 Dec 2018.

Submit your article to this journal $\pi$

Џ Article views: 21

View Crossmark data $₫$ 


\title{
Response of Amaranthus cruentus cv Mexicano to nitrogen fertilization under irrigation in the temperate, semiarid climate of North Patagonia, Argentina
}

\author{
María Fany Zubillagaa,b,c, Ricardo Camina ${ }^{c}$, Gustavo Adolfo Oriolia, ${ }^{a, b}$, and \\ Daniel Alejandro Barrio ${ }^{a, b}$ \\ a Universidad Nacional de Río Negro, Viedma, Argentina; ${ }^{b}$ Consejo Nacional de Investigaciones Cientificas y \\ Tecnicas (CONICET), Buenos Aires, Argentina; 'Universidad Nacional del Sur, Bahia Blanca, Argentina
}

\begin{abstract}
This article explores the response of three genotypes of Amaranthus to different sowing date and to different doses of nitrogen $(\mathrm{N})$ fertilization. The experimental design was a randomized complete block design with three replicates for cultivars, planting date and fertilization per treatment. Mexicano sown in early December had the best yield $\left(5285 \mathrm{~kg} \mathrm{ha}^{-1}\right)$ with highly significant differences $(p<0.001)$ respect to Dorado and Antorcha. To assess the $\mathrm{N}$ fertilization Mexicano cultivar was sown at the end of spring (1 December). Morphophysiological variables increased as the $\mathrm{N}$ fertilization dose was raised. Higher doses of $\mathrm{N}$ fertilizer resulted in greater economic yields this was mainly due to the increase in grain number rather than that of a 1000 grain weight. The results of this investigation suggest that sowing Amaranthus cruentus cv Mexicano on 1 December with $150 \mathrm{~kg} \mathrm{~N} \mathrm{ha}{ }^{-1}$ favors its general development and allows to obtain high economic and biological yields with an appropriate protein content.
\end{abstract}

\section{ARTICLE HISTORY}

Received 14 July 2016

Accepted 27 February 2018

\section{KEYWORDS}

nitrogen; alternative agriculture; phenology

\section{Introduction}

Amaranth (Amaranthus spp.) is an ancient plant that was seeded 5,000 years ago in hundreds of hectares by the pre-Columbian civilizations. It is considered to have originated in the central and south Americas, with Mexico as a country of reference (Stallknecht and Schulz-Schaeffer 1993). Several studies have reported that amaranth as well as maize and legumes were an integral food component of numerous indigenous populations (Mapes and Espitia 2010).

Amaranthus belongs to the group of plants designated as having the $\mathrm{C} 4$ carbon metabolism pathway. This group is characterized by having a wide diversity and genetic variability; innumerable morphological traits; health-promoting properties, as well as agronomic, nutritional and industrial uses (Barba De La Rosa, Silva-Samchez, and González De Mejia 2007). Another characteristic that distinguishes these plants is their nutritional composition. The grain of the amaranth has been cited by many authors as containing from 10 to $20 \%$ proteins with a favorable balance of amino acids (Lehmann 1990; Barba De La Rosa et al. 1992; Zheleznov, Solonenko, and Zheleznova 1997). Its adaptive features and nutritional quality make of the amaranth a promising crop for diversification in both large and small farms (Bejosano and Corke 1998).

Technically, the amaranth is considered a pseudocereal since the plant has characteristics similar to those of the true monocotyledoneous cereal grains but, being a dicotyledoneous, is not 
considered in that category. Like those, however, Amaranthus contains high starch content, but differs from them in that it is stored in the perisperm while the embryo occupies a large part of the grain, there constituting a rich source of lipids and proteins (Segura Nieto, Barba de la Rosa, and Paredes López 1994).

The sowing time has a direct impact on yields of crops. An optimum planting date allows the growth and development of the plants and these, flourish and fructify under optimum physiology requirements (O'Brien and Price 2008). In early sowing, the flowering stage is more exposed to late frozen and that reduces crop development, which affects the crop yield. Late sowing, produces a shortening of different phenology stages due to the incidence of short days (less daylight hours) and high temperatures. The plant that grows under these conditions has lower height, reduction of foliar area, beforehand ripening and eventually the reducing of yield and its components (Barros, Carvalho, and Basch 2004; O’Brien and Price 2008).

Each genotype has a differential response at the ambient condition and this influences the growth of the plant and the possibility of reaching physiologic maturity. Photoperiod and temperature play an important role to define the sowing moment because it conditions the beginning and duration of different phenology stages and consequently the total length of growth cycle (Boote et al. 1994).

Amaranth grows vegetative in long days and flowers when days begin to shorten. The growth reduces when temperature and luminous intensity decreases (Kigel 1994). As described before, time of sowing and genotype have an important effect of biological and economics yields

Information regarding the production and commercialization of this crop is scarce, with some data from Argentina, which are both variable and marginal (Lezcano 2013). The amaranth has potential grain yield, with a high content of lysine-containing proteins (Barba De La Rosa, SilvaSamchez, and González De Mejia 2007) and a gluten-free composition, can be a nutritionally advantageous crop, especially for gluten-intolerant individuals (Gallagher, Gormley, and Arendt 2004). These characteristics indicate the amaranth as an alternative crop of great future.

The rich protein content of this crop supports a potentially beneficial effect of nitrogenous fertilization on yield, protein content, and other biometrics characteristics of the plant. In fact, nitrogen $(\mathrm{N})$ has been assessed as the most limiting element for this plant's growth, so high doses of $\mathrm{N}$ fertilizer are recomended (Stallknecht and Schulz-Schaeffer 1993). Studies carried out under different environmental conditions have demonstrated that the increase in protein yield in response to $\mathrm{N}$ fertilization result from an elevation in the overall plant biomass as well as the number of seeds both per plant and per unit leaf surface area (Espitia 1992; Diaz Ortega et al. 2004; Pospisil et al. 2006).

An optimal management of $\mathrm{N}$ fertilization during the initial stages in the development of the plant results in a greater efficiency in the utilization of the other available resources for the ultimate growth and yield of the crop (Stallknecht and Schulz-Schaeffer 1993). Moreover, during years when the environmental conditions (temperature and rainfall) have proven favorable, the crops have been found to produce optimal yields of proteins at low levels of $\mathrm{N}$ input $\left(60 \mathrm{~kg} \mathrm{~N} \mathrm{ha}{ }^{-1}\right)$, and even without any fertilization (Elbehri, Putnam, and Schmitt 1993; Myers 1998; Pospisil et al. 2006). In contrast, during dry years, with unfavorable conditions for organic matter mineralization, doses as high as $100 \mathrm{~kg} \mathrm{~N} \mathrm{ha}^{-1}$ were needed to increase the biological yield, 1000 grain weight, and the length of the inflorescence (Elbehri, Putnam, and Schmitt 1993; Myers 1998; Pospisil et al. 2006).

High fertilizer doses $\left(180 \mathrm{~kg} \mathrm{~N} \mathrm{ha}^{-1}\right)$, however, can produce adverse effects on any harvested crop. They include, for example, an excessive increase in plant height with a subsequent lodging of the stems, and a prolongation of the maturation period of the seeds (Elbehri, Putnam, and Schmitt 1993; Myers 1998). Other authors, however, have reported favorable responses to fertilization doses above $120 \mathrm{~kg} \mathrm{~N} \mathrm{ha}^{-1}$ without any plant lodging of the stems (Schulte et al. 2005). Nevertheless, numerous studies have shown that fertilization exerts absolutely no effect on the 


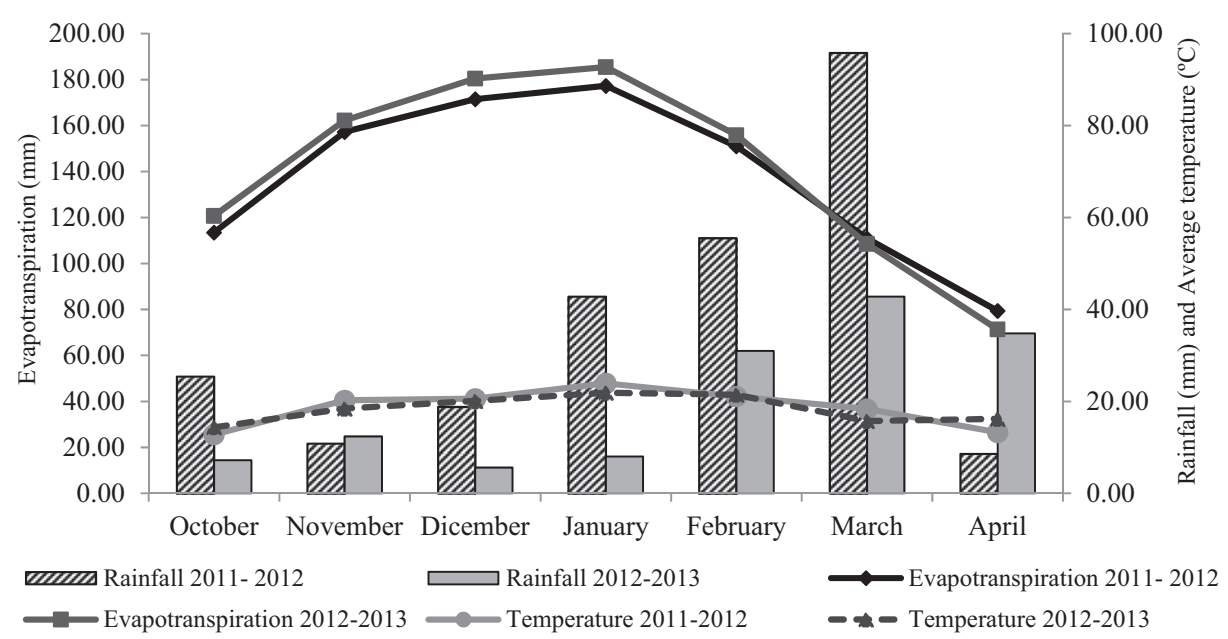

Figure 1. Average monthly temperature $\left(\mathrm{T}^{\circ}\right)$, rainfall, and evapo-transpiration (ET) during the crop productive cycle in the study years despite the climatic data were registered daily, they are shown as average values per month.

protein content of the amaranth grain (Elbehri, Putnam, and Schmitt 1993; Aufhammer, Kubler, and Lee 1999; Žajová, Koštál, and Verešćák 2001; Peterka et al. 2001).

The objective was to evaluate the effect of cultivars, sowing date and nitrogenous fertilization on the biometric and production parameters in an irrigated crop of Amaranthus, with better productive performance under the agroecologic conditions of a temperate, semidesertic climate in the lower Río Negro valley, Province of Río Negro, Argentina.

\section{Materials and methods}

\section{Site location, description, and climatic conditions}

Field experiments were conducted at the Experimental Agricultural Station of the lower Río Negro valley (INTA-Estación Experimental Agropecuaria Valle Inferior del Río Negro; $40^{\circ} 48^{\prime} \mathrm{S}$, $63^{\circ} 05^{\prime} \mathrm{W}, 4 \mathrm{~m}$ above sea level). Climate data during the study years are shown in Figure 1.

The initial physicochemical characteristics of the upper $50 \mathrm{~cm}$ of the experimental loam soil were: $\mathrm{pH}$ (8.20); electrical conductivity $\left(1.2 \mathrm{mmhos} \mathrm{cm}^{-1}\right)$; organic matter $(3,8 \%)$; total nitrogen $(0,18 \%) ; \mathrm{N}^{-} \mathrm{NO}_{3}\left(24.60 \mathrm{mg} \mathrm{kg}{ }^{-1}\right) ; \mathrm{P}$ (Olsen, $\left.16.60 \mathrm{mg} \mathrm{kg}^{-1}\right) ; \mathrm{S}\left(14.7 \mathrm{mg} \mathrm{kg}^{-1}\right.$ as a $\left.\mathrm{SO}_{4}{ }^{-}\right) ; \mathrm{Ca}$ $\left(8.230 \mathrm{mg} \mathrm{kg}^{-1}\right) ; \mathrm{Mg}\left(1.170 \mathrm{mg} \mathrm{kg}^{-1}\right)$; sodium-adsorptión ratio (1.83). The soil characterization was provided by analysis laboratory of: soil, water and plant tissues by INTA-Estación Experimental Agropecuaria. Prior to the start of the field experiments, the experimental plots had been under fallow for a year.

\section{Crop management and experimental design}

The cultivars used in the experiments were A. cruentus cv Mexicano, A. hypocondriacus cv Antorcha and A. hypocondriacus cv Dorado.

The experimental design was a randomized complete block design with three replicates for cultivars, planting date and fertilization per treatment. At sowing, the experimental design comprised three $14 \mathrm{~m}^{2}$ plots (four furrows $0.7 \mathrm{~m}$ wide $\times 5.0 \mathrm{~m} \mathrm{long}$ ). When plants reached $20-30 \mathrm{~cm}$ height, weeding was performed manually; thinning was also made by hand leaving 10 plant $\mathrm{m}^{-2}$. Furrow irrigation was applied according to the soil-moisture retention curve before reaching the permanent-wilting point with a total lamina of $800 \pm 50 \mathrm{~mm}$. 
For cultivars and sowing date assays all the cultivars were used. Seeding was performed in the cycles 2010/11 (10 November, 1 December, 22 December and 11 January) and 2011/12 (10 November, 1 December, 22 December and 11 January).

To assess the $\mathrm{N}$ fertilization the used cultivar was A. cruentus cv Mexicano considering that it showed a better performance in the preliminary cultivars results in the year 2010. Seeding was performed in straight-line by hand, sowing at the end of spring (30 November 2011 and 1 December 2012) according to the preliminary sowing date results in the year 2010. The experimental design was performed as previously described. The treatments involved the following doses of $\mathrm{N}$ in the form of hand-added granulated urea $(46 \% \mathrm{~N}): 0 \mathrm{~kg} \mathrm{~N}^{-1}$ (control); $50 \mathrm{~kg} \mathrm{~N}$ $\mathrm{ha}^{-1} ; 100 \mathrm{~kg} \mathrm{~N} \mathrm{ha}^{-1} ; 150 \mathrm{~kg} \mathrm{~N} \mathrm{ha}^{-1}$; and, $300 \mathrm{~kg} \mathrm{~N} \mathrm{ha}^{-1}$. Each fertilization treatment was divided into two doses: half when plants had grown to a height of $60 \mathrm{~cm}$, and the second half at the beginning of the inflorescence stage.

Ten plants were selected randomly for the measurement of the biometrics variables. They were tagged in each subparcel, and the following data were measured during the growth cycle: number of visible leaves at the beginning of panicle formation (VLN), maximum foliar area (MFA) and maximun number of leaves $(\mathrm{ML})$, nodes $(\mathrm{MN})$, and ramifications (MR). Also, the following phenological stages were chronologically registered (days after seeding) during the growth cycle as described by Henderson (1993): plant emergence (E), initiation of panicle development (IP); initation of anthesis (IA); milky grain (MG); dough grains (DG), and physiological maturity (PM). The growing-degree days (GDD) for the total growth cycle (seeding to physiological maturity) were calculated according to McMaster and Wilhelm (1997).

At the end of the growth cycle, the tagged plants in each treatments were harvested, and plant height $(\mathrm{PH})$, panicle length (PL) and stem diameter (SD) were measured. Thereafter, plants were dried at $60^{\circ} \mathrm{C}$ to constant weight. Leaves (LW), stems (SW), and panicles including grains (PW) were weighed to obtain the total aerial plant biomass (aBW). Each panicle was threshed by hand; grains were cleaned by a forced-air current, and grain number (GNp), dry weight (GWp) and 1000 grain weight (TGW) were recorded. The inflorescence dry weight (IW) was calculated as the difference between the total panicle weight (PW) and the grain weight per panicle (GWp).

The plants of the central furrows were harvested manually to obtain economic yields (EY) and biological yields (BY), and the number of plants on a hectare basis (DpH). The harvest index (HI) was calculated as the quotient between EY ( $\mathrm{kg}$ of grain ha ${ }^{-1}$ ) and BY (biomass $\mathrm{kg} \mathrm{ha}^{-1}$ ).

The $\mathrm{N}$ content was determined at the time of harvesting by the Kjeldahl method. It was then multiplied by 6.25 to estimate the percent of crude protein. Since we noticed the appearance of the pathogenic fungus Macrophoma spp., the percentage of affected plants as judged by the appearance of black spots on the stems was recorded to determine its incidence.

\section{Statistical analysis}

The data collected were analyzed by the statistical program INFOSTAT (Di Rienzo et al. 2008). The combined variables for both of the years studied were evaluated statistically by the analysis of variance (ANOVA). For each year the design utilized was in complete blocks at random. In fertilization assay a quadratic model was adjusted for those variables that followed the plants behavior; the theoretical value of the maximum attainable response $\left(\mathrm{Y}_{\max }\right)$ was determined along with the corresponding maximum fertilizer dose $\left(\mathrm{X}_{\max }\right)$ after Bélanger et al. (2000). Nevertheless, because the derivative at the point in the curve where this value was reached was small, we opted to ascertain the response to the previous penultimate dose (PD), and how much the latter value represented with respect to the maximum attainable response. In those variables in which the model could not be adjusted, we performed a pairwise-comparison test at a significance level of $5 \%$. 
Table 1. Average values of economic yield of different cultivars of Amaranthus in different sowing date during the production cycles.

\begin{tabular}{|c|c|c|c|c|c|c|}
\hline \multirow{2}{*}{$\begin{array}{l}\text { Production cycle } \\
\text { Cultivar/ } \\
\text { sowing date }\end{array}$} & \multicolumn{3}{|c|}{$2010-2011$} & \multicolumn{3}{|c|}{$2011-2012$} \\
\hline & $\begin{array}{l}\text { Mexicano } \\
\left(\mathrm{kg} \mathrm{ha}^{-1}\right)\end{array}$ & $\begin{array}{l}\text { Dorado } \\
\left(\mathrm{kg} \mathrm{ha}^{-1}\right)\end{array}$ & $\begin{array}{l}\text { Antorcha } \\
\left(\mathrm{kg} \mathrm{ha}^{-1}\right)\end{array}$ & $\begin{array}{l}\text { Mexicano } \\
\left(\mathrm{kg} \mathrm{ha}^{-1}\right)\end{array}$ & $\begin{array}{l}\text { Dorado } \\
\left(\mathrm{kg} \mathrm{ha}^{-1}\right)\end{array}$ & $\begin{array}{l}\text { Antorcha } \\
\left(\mathrm{kg} \mathrm{ha}^{-1}\right)\end{array}$ \\
\hline First date & $4264 \mathrm{f}$ & $4465 \mathrm{e}$ & $3930 \mathrm{~g}$ & $3650 \mathrm{c}$ & $2589 \mathrm{~g}$ & $3425 d$ \\
\hline Second date & 5285 a & $4622 \mathrm{~d}$ & $4809 \mathrm{c}$ & 4323 a & $2717 \mathrm{~g}$ & $3571 \mathrm{~cd}$ \\
\hline Third date & $5085 \mathrm{~b}$ & $4260 \mathrm{f}$ & 4392 e & $4066 \mathrm{~b}$ & $2879 \mathrm{f}$ & 3232 e \\
\hline Fourth date & $2055 \mathrm{~h}$ & $2012 \mathrm{~h}$ & $2005 \mathrm{~h}$ & $1011 \mathrm{~h}$ & $720 \mathrm{i}$ & $1011 \mathrm{~h}$ \\
\hline
\end{tabular}

Each value is the mean of $n=6$. Values of the same production cycle followed by the same letter are not statistically different $(p>0.05)$ by the Fisher least-significant-difference test.

Table 2. Economic yield and its components, biological yield and plant density at harvesting time on Amaranthus cruentus cv Mexicano.

\begin{tabular}{|c|c|c|c|c|c|c|c|c|c|c|}
\hline \multirow[b]{2}{*}{ Variable } & \multicolumn{5}{|c|}{ Dose of fertilization $\left(\mathrm{kg} \mathrm{N} \mathrm{ha}^{-1}\right)$} & \multirow[b]{2}{*}{$\mathrm{R}^{2}$} & \multirow[b]{2}{*}{$X_{\max }$} & \multirow[b]{2}{*}{$Y_{\max }$} & \multirow[b]{2}{*}{ PD } & \multirow[b]{2}{*}{$\% \mathrm{MR}$} \\
\hline & 0 & 50 & 100 & 150 & 300 & & & & & \\
\hline $\mathrm{EY}\left(\mathrm{kg} \mathrm{ha}^{-1}\right)$ & 1421 & 2206 & 3441 & 4123 & 4329 & 97 & 245 & 4514 & 150 & 91 \\
\hline GWp (g) & 19.69 & 28.60 & 35.81 & 42.04 & 47.27 & 96 & 276 & 47.53 & 150 & 88 \\
\hline TGW (g) & 0.77 & 0.80 & 0.84 & 0.85 & 0.87 & 96 & 268 & 0.87 & 150 & 97 \\
\hline GNp & 25,650 & 35,900 & 42,940 & 49,280 & 54,240 & 95 & 267 & 54,680 & 150 & 90 \\
\hline BY $\left(\mathrm{kg} \mathrm{ha}^{-1}\right)$ & 7802 & 12,074 & 18,207 & 20,931 & 21,806 & 96 & 238 & 22,940 & 150 & 91 \\
\hline $\mathrm{DpH}\left(\mathrm{ha}^{-1}\right)$ & 76,759 & 79,860 & 90,248 & 90,737 & 90,889 & 85 & 222 & 93,100 & 150 & 97 \\
\hline
\end{tabular}

Each value is the mean of $n=6$.

EY, economic yield; GWp, grain dry weight per panicle; TGW, thousand-grain weight; GNp, grain number per panicle; BY, biologic yield; $\mathrm{DpH}$, density of plants per ha at harvesting time; $\mathrm{R}^{2}$, determination coefficient of the quadratic model; $X_{\max }$ maximum fertilizer dose; $Y_{\max }$ maximum response to fertilizer dosage; PD (penultimate dose), previous dose to the theoretical maximum; \%MR, percent of the maximum response (YPD relative to $Y_{\max }$ or $Y 300$ ).

\section{Results}

\section{Cultivars and sowing date}

As can be seen in Table 1 the three cultivars showed better productive performance in the second and third sowing dates, with significant differences $(\mathrm{p}<0.001)$. Mexicano had the best yield $\left(5285 \mathrm{~kg} \mathrm{ha}^{-1}\right)$ with highly significant differences $(\mathrm{p}<0.001)$ compared to Dorado and Antorcha reaching 4622 and $4809 \mathrm{~kg} \mathrm{ha}^{-1}$ on the second sowing date in 2010/11. On the other hand, in the second cycle of growing (2011/12), the behavior of the cultivars and sowing dates was similar to the first cycle, however a tendency to decrease yield was observed.

\section{Nitrogen fertilization}

Higher doses of $\mathrm{N}$ fertilizer resulted in a greater EY (Table 2) this was mainly due to the increase in GNp rather to that of a TGW. This positive effect, however, essentially leveled off for the overall yield beyond the dose of $150 \mathrm{~kg} \mathrm{~N} \mathrm{ha}^{-1}$ (Table 2).

With reference to biometrics viariables, the media value for VLN was 16, with no difference between treatments. Most of the morphophysiological variables showed an increase as the $\mathrm{N}$ fertilization dose increased (Table 3). However, SD and MN were similar at fertilizer doses of 150 and $300 \mathrm{~kg} \mathrm{~N} \mathrm{ha}^{-1}$.

The aBW and its components increased significative $(\mathrm{p}<0.001)$ as $\mathrm{N}$ fertilization increased (Table 3). The maximum values for all the variables (PH, PL, ML, MR, MFA, SW, PW, LW, aBW) were obtained with the dose of $300 \mathrm{~kg} \mathrm{~N} \mathrm{ha}^{-1}$. PW was the greatest among the studied biometric parameters, showing the peculiarity that the dry weight ratio "grain/inflorescence without grain" increased as the $\mathrm{N}$ fertilization dose increased (Figure 2). 
Table 3. Average values of biometrics variables, aerial plant biomass and its components and crude protein concentration (\%) on Amaranthus cruentus cv Mexicano.

\begin{tabular}{|c|c|c|c|c|c|c|}
\hline \multirow[b]{2}{*}{ Variable } & \multicolumn{5}{|c|}{ Fertilizer dosage $\left(\mathrm{kg} \mathrm{N} \mathrm{ha}^{-1}\right)$} & \multirow[b]{2}{*}{ Significance $(p)$} \\
\hline & 0 & 50 & 100 & 150 & 300 & \\
\hline $\mathrm{PH}(\mathrm{cm})$ & $149.50 \mathrm{e}$ & $162.0 \mathrm{~d}$ & $174.0 \mathrm{C}$ & $176.0 \mathrm{~b}$ & $182.0 \mathrm{a}$ & $<0.0001$ \\
\hline $\mathrm{PL}(\mathrm{cm})$ & $26.83 \mathrm{e}$ & $35.50 \mathrm{~d}$ & $44.05 \mathrm{c}$ & $49.00 \mathrm{~b}$ & $52.89 a$ & $<0.0001$ \\
\hline$M L$ & $32.00 \mathrm{~d}$ & $35.16 \mathrm{c}$ & $35.83 \mathrm{c}$ & $37.50 \mathrm{~b}$ & $40.17 \mathrm{a}$ & $<0.0000$ \\
\hline MN & $31.26 \mathrm{~d}$ & $32.28 \mathrm{~cd}$ & 33.22 bc & $34.00 \mathrm{ab}$ & $34.89 \mathrm{a}$ & $<0.0002$ \\
\hline MR & $2.17 \mathrm{~d}$ & $4.00 \mathrm{C}$ & $4.33 \mathrm{c}$ & $6.33 b$ & $8.16 \mathrm{a}$ & $<0.0001$ \\
\hline MFA $\left(\mathrm{cm}^{2}\right)$ & $1387 \mathrm{~d}$ & $1569 \mathrm{c}$ & $1718 \mathrm{c}$ & $1905 \mathrm{~b}$ & $2318 a$ & $<0.0001$ \\
\hline $\mathrm{SD}(\mathrm{cm})$ & $1.50 \mathrm{c}$ & $1.56 \mathrm{c}$ & $2.00 \mathrm{~b}$ & $2.20 \mathrm{a}$ & $2.32 \mathrm{a}$ & $<0.0001$ \\
\hline SW (g) & 20.89 e & $29.17 \mathrm{~d}$ & $41.39 \mathrm{c}$ & $44.36 \mathrm{~b}$ & $51.08 \mathrm{a}$ & $<0.0001$ \\
\hline PW (g) & $26.24 \mathrm{e}$ & $41.65 \mathrm{~d}$ & $71.07 \mathrm{C}$ & $76.46 \mathrm{~b}$ & $82.17 \mathrm{a}$ & $<0.0001$ \\
\hline LW $(\mathrm{g})$ & $10.18 \mathrm{e}$ & $15.66 \mathrm{~d}$ & $23.99 \mathrm{c}$ & $28.80 \mathrm{~b}$ & $33.00 \mathrm{a}$ & $<0.0001$ \\
\hline aBW & $57.30 \mathrm{e}$ & $86.48 d$ & $136.45 \mathrm{c}$ & $149.62 \mathrm{~b}$ & $166.25 \mathrm{a}$ & $<0.0001$ \\
\hline$\% \mathrm{Ps}$ & $2.94 \mathrm{C}$ & $3.35 c$ & $4.17 b c$ & $4.77 \mathrm{~b}$ & $6.16 \mathrm{a}$ & $<0.0001$ \\
\hline$\% \mathrm{PI}$ & $13.27 \mathrm{e}$ & $13.89 \mathrm{~d}$ & $15.32 \mathrm{c}$ & $16.40 \mathrm{~b}$ & $17.30 \mathrm{a}$ & $<0.0001$ \\
\hline$\% \mathrm{Pg}$ & $16.19 \mathrm{~d}$ & $17.27 \mathrm{c}$ & $18.70 \mathrm{~b}$ & $19.80 \mathrm{a}$ & $19.72 \mathrm{a}$ & $<0.0001$ \\
\hline
\end{tabular}

Each value is the mean of $\mathrm{n}=6$.

$\mathrm{PH}$, plant height; $\mathrm{PL}$, panicle length; $\mathrm{ML}$, maximum leaf count, $\mathrm{MN}$, maximum node count; $\mathrm{MR}$, maximum ramification count; MFA, maximum foliar area; SD, stem diameter SW, stem dry weight; PW, panicle dry weight; LW, leaf dry weight; aBW, aerial-plant-biomass dry weight, \%Ps: crude protein concentration (\%) of stem, \%PI: crude protein concentration (\%) of leaf, \%Pg: crude protein concentration of grain (\%). Values of the same variable followed by the same line are not statistically different $(p>0.05)$ by the Fisher least-significant-difference test.

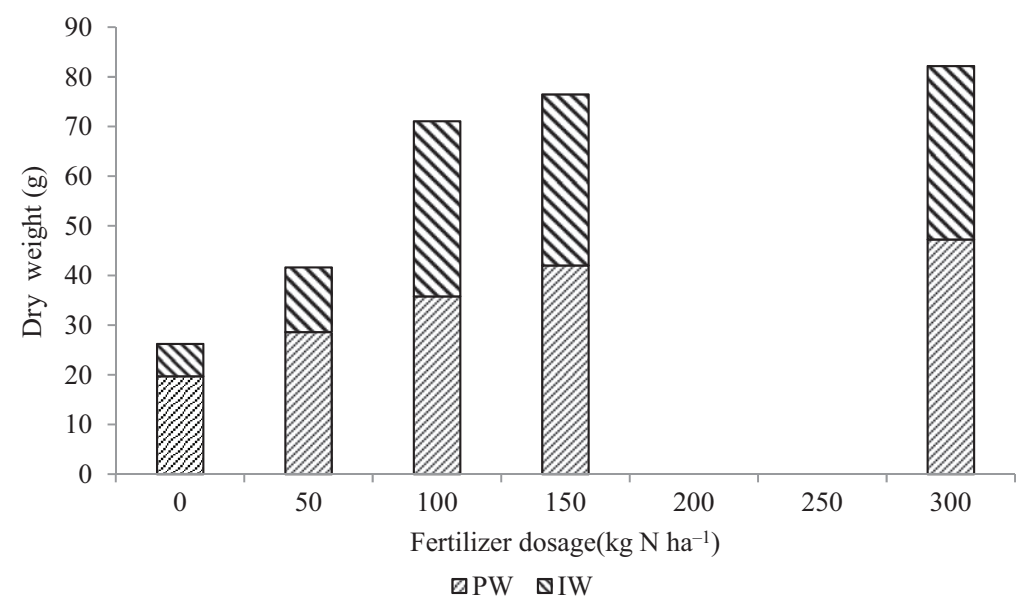

Figure 2. Dry weights of the panicle (PW) and inflorescence (IW). Each value is the mean of $n=6$.

As evidenced after the appropriate adjustment of the quadratic model greater the $\mathrm{N}$ fertilizer dose, the greater BY of Amaranthus cruentus cv Mexicano. The optimal dose of $\mathrm{N}$ was $150 \mathrm{~kg}$ $\mathrm{ha}^{-1}$. Increased $\mathrm{N}$ fertilization also resulted in a greater $\mathrm{DpH}$, even though the determination coefficient was only $85 \%$ (Table 2 ).

Values for HI did not adjust to the quadratic model. Nevertheless, values on control plants $(18 \%)$ were significantly different $(\mathrm{p}<0.01)$ than those on plants fertilized with $300 \mathrm{~kg} \mathrm{~N}$ $\mathrm{ha}^{-1}(20 \%)$.

The percentage of crude-protein concentration of plant stems, leaves, and grains also responded positively to increments in the $\mathrm{N}$ fertilization (Table 3 ).

The percentage of the plants affected by the fungus Macrophoma spp was reduced from $2.0 \%$ to $0.5 \%$ as fertilization increased up to $100 \mathrm{~kg} \mathrm{~N} \mathrm{ha}^{-1}$. However, no further decreases occurred thereafter (data not shown). 
Table 4. Average values (days) after seeding for different phenological phases, and total growing-degree days, at various $\mathrm{N}$ fertilization doses during the productive cycles.

\begin{tabular}{lccccccc}
\hline & \multicolumn{7}{c}{ Days after seeding } \\
\cline { 2 - 7 } Fertilizer dosage $\left(\mathrm{kg} \mathrm{N} \mathrm{ha}^{-1}\right)$ & $\mathrm{E}$ & $\mathrm{IP}$ & $\mathrm{IA}$ & $\mathrm{MG}$ & $\mathrm{DG}$ & $\mathrm{PM}$ & GDD \\
\hline 0 & 5.33 & 45.15 & 63.20 & 115.20 & 128.20 & $140.00 \mathrm{~d}$ & $1.678 \mathrm{~b}$ \\
50 & 5.33 & 44.83 & 62.80 & 115.30 & 128.00 & $140.30 \mathrm{~d}$ & $1.678 \mathrm{~b}$ \\
100 & 5.17 & 44.67 & 62.70 & 116.00 & 129.20 & $143.30 \mathrm{C}$ & $1.700 \mathrm{ab}$ \\
150 & 5.33 & 44.00 & 62.20 & 116.30 & 130.30 & $145.20 \mathrm{~b}$ & $1.714 \mathrm{ab}$ \\
300 & 5.33 & 43.50 & 62.50 & 116.80 & 130.20 & $146.30 \mathrm{a}$ & $1.722 \mathrm{a}$ \\
\hline
\end{tabular}

E, emergence; IP, initiation of panicle development; IA, initiation of anthesis; MG, milky grain; DG, drough grain; PM, physiological maturity; GDD, growing-degree days.

Respect to phenology phases, nitrogen fertilization increased in 6 days the time period from sowing to physiological maturity. When expressed in growing-degree days, the increment was 44 GDD (Table 4).

\section{Discussion}

In the evaluated cultivars the 1st, 2nd and 3ed sowing dates allowed the finishing their phenological development. The plants in this sowing date showed (respect to 4 th sowing date) a normal high, well-developed of panicles, abundant foliar area and more number of grain per panicle (data not shown). This behavior might be associated to the agroclimatical condition of the study zone, which allowed an appropriate development of plants in their different phenologic stages. By contrast, in the 4 th sowing date the phenological stages cycle was reduced possibly in response to factors like radiation, photoperiod and temperature, which decreases by the end of the summer. Under these conditions the plant shortened their phenological stages for completing their life cycle, for this, induced early flowering with less plant development and this impacts negatively in grain number, and this in economic yield.

The behavior described above was observed in both years and in the different cultivars presumably due to the incidence of temperatures less than $8{ }^{\circ} \mathrm{C}$ (amaranth base temperature) during the end of summer and for photosensitive response of this crop during development (Pedroza 1989; Mujica, Berti, and Izquierdo 1997) Amaranth species need for complete development days with temperatures above $12^{\circ} \mathrm{C}$ and 12 hours of illumination per day (Bavec and Mlakar 2002). However, another authors demonstrate that some amaranth exemplars have sensibility to differences in length day, some of them flowering and producing seeds in less than three month if they were sown in short photoperiod (less than $12 \mathrm{hs).} \mathrm{Under} \mathrm{these} \mathrm{condition} \mathrm{the} \mathrm{height} \mathrm{of} \mathrm{plants}$ and the number of plant per hectare were reduced (Wu et al. 2000; Whitehead, Carter, and Singh 2002). The shortening of days before summer often affected development of amaranth plants (Kigel 1994; Khandaker, Masum, and Akond 2009).

Some experiment done in different zones of Argentina, with different species of amaranth demonstrated than late sowing dates (between end of November and January) reduced plant height, biomass, grain yield and showed more loss plant at harvest. This effect reduces the number of days to complete development phonological cycle, because there are less light levels and low environmental temperatures during grain filling (Vargas López, Covas, and Bailac 1993; Agamennoni 1995; Troiani, Sánchez, and Reinaudi 2004).

The economic yields obtained in the different sowing date evaluated in this trials were higher than yields published in the Pampean region, Argentina (Agamennoni 1995; Troiani, Sánchez, and Reinaudi 2004; Reinaudi, et al. 2011) and in others parts of the world (FAO 1993; Williams and Brenner 1995; Gimplinger et al. 2007), presumably due to agroclimatic conditions and to the availability of water irrigation. 
In relation with the time of sowing, early December (second sowing date of this trail) could be considered more appropriate for the sowing of amaranth in this region because it achieves the highest yields for all cultivars in most cases.

In respect to cultivars, Mexicano was that reached the best economic yield respect to the other genotypes (A. hypocondriacus cv Antorcha and cV Dorado) in semiarid climate of north Patagonia.

Putnam (1990), describes that some amaranth's characteristics can be expressed or repressed according to the environmental conditions of the production site, determined by the morphological plasticity of the crop.

Previous investigations on amaranth have demonstrated that $\mathrm{N}$ fertilization increased total plant biomass, grain yield, panicle length, panicle number per plant, and number of seeds per $\mathrm{m}^{2}$ (Elbehri, Putnam, and Schmitt 1993; Myers 1998; Diaz Ortega et al. 2004; Schulte et al. 2005; Pospisil et al. 2006). In contrast to these results, other authors have reported that neither yield nor harvest index was altered by $\mathrm{N}$ enrichment of the soil (Makus 1990; Diaz Ortega et al. 2004; Gunda et al. 2005; Schulte et al. 2005).

The mathematical model utilized here permitted an estimation of the fertilization dose required for attaining a maximum yield, although this dose would vary with the preexisting amounts of nitrogen in the soil. The difference in yield recorded between the $\mathrm{N}$ levels of 150 and $300 \mathrm{~kg} \mathrm{~N} \mathrm{ha}^{-1}$ was about $200 \mathrm{~kg} \mathrm{ha}^{-1}$ of grain. The adjusted yield determined a dose of $245 \mathrm{~kg} \mathrm{~N}$ $\mathrm{ha}^{-1}$ as necessary for reaching the maximum EY of $4514 \mathrm{~kg} \mathrm{ha}^{-1}$.

All the biometricts variables were enhanced by $\mathrm{N}$ fertilization. The amount of resources allocated to reproductive structures often depends on plant size. However, it has been shown that resource allocation to those structures can increase, decrease, or remain constant relative to plant-size variations depending on the species and environmental influences (Bazzaz and Ackerly 1992; Reekie 1998; Welham and Setter 1998). The present study demonstrates that resource allocation within the plant favors the increase in size of floral structures as a response to increments in soil nitrogen. This improves could be associated with the rise in size of morphological variables as can be seen in Table 3.

A substantial finding among the biometric variables was that VLN, under all the experimental conditions, was about 16 per plant at the begining of panicle development. The conistency of this trait suggests that it is a genetic characteristic of the particular cultivar used (i.e., Mexicano).

At harvest, both $\mathrm{PH}$ and SD were increased with fertilizer additions. This agrees with reports of other authors (Myers 1998; Alonge et al. 2007; Olaniyi, Adelasoye, and Jegede 2008; Ainika, Auwalu, and Yusuf 2011). The difference in plant height among the experimental groups was a result of differences in the magnitude of internode elongation. This was a response to an increased plant density, and subsequent increase in intraspecific competition for sun radiation (Gimplinger et al. 2008; Yarnia 2010). Increments in SD were concomitant with a rise in PW. Thickest stems are necessary to sustain panicles of greater length and weight, and reduce possible lodging. In a similar cultivation system, Arellano Vázquez and Galicia Franco (2007) demonstrated that at high levels of $\mathrm{N}$ fertilization grain yield was greater; the incidence of plant illness was reduced but at the expense of a higher percentage of bended stems. They also found no differences in plant density, stem diameter, or leaf length as a result of treatments.

The observed increase in the aBW, and the correspondingly greater number and total area of leaves, most likely resulted in a higher level of the intercepted photosyntetic active radiation (Randy 1991; Yarnia 2010; Zhang et al. 2014). These effects of $\mathrm{N}$ fertilization were greatly reflected in an increased PW (40\%), which was mostly attributed to an increased GNp and to the TGW to a lesser extent. These increases could be considered as part of the plant's genetically determined response to $\mathrm{N}$ fertilization, wherein grain number per panicle became notably elevated rather than the weight of the grain or the inflorescence. Nevertheless, the increase in EY because of $\mathrm{N}$ enrichment was the result of the increased both GNp and $\mathrm{DpH}$. 
The maximum increases observed in the crude-protein concentrations of grains in the $\mathrm{N}$ fertilized plants (over the control values) were 3.6\% (from 16.2\% to 19.8\%). In general, the protein content of an amaranth grain varies between 10 and 21\% (Lehmann 1990; Makus 1990; Barba De La Rosa et al. 1992; Zheleznov, Solonenko, and Zheleznova 1997; Schulte et al. 2005). Our results agree with those findings not only with respect to the range of crude protein values but also with the effect of $\mathrm{N}$ enrichment on the crude-protein levels of the different plant structures (Table 3). The significance of these increases in the crude-protein content in grains and in various plant fractions lies not only in the greater amount of protein, but also in the potential enhancement of the nutritional quality of these grains. This might be due to an associated increase in aminoacids such as lisine (not measured in this study) which is limited in cereals.

The reduction in the black fungal spotting occurring at the highest $\mathrm{N}$ fertilization doses could be attributed to both enhances of the stem vigor and increases in the tolerance to the disease. This can be the result of the better nutritional status even thought the desease is intimately related to the cultivar susceptibility (Arellano Vázquez and Galicia Franco 2007). Certain authors attribute plant bending directly to the incidence of stem spotting since the fungal infection penetrates to the internal tissues, weakening them (Sanchez, Espitia, and Osada Kawasoe 1991).

We found that increments in the levels of $\mathrm{N}$ fertilization showed a tendency towards extending the length of the growth cycle; there was a statistically significant difference $(p<0.01)$ of 44 growing-degree days between the control plants and those cultivated at the maximum fertilization rate. This modest increment in the duration of the growth cycle could nevertheless be of importance because of the beginning of the autumn rainfall season could impose some difficulties in harvesting the crop. The results obtained indicate that the observed differences started when grains were at the milky stage and became more evident toward the end of the growth cycle. Myers (1998) in a study similar to ours, demonstrated that a dose of $180 \mathrm{~kg} \mathrm{~N}^{-1}$ prolonged the vegetative period while delaying the maturation of grains. However, Diaz Ortega et al. (2004) found no differences associated with the experimental treatments. On the other hand, several authors demonstrated an increase in the number of days among different growth stages, resulting in a prolongation of the vegetative period when a fertilizer was applied (Kho 2000; Prasad et al. 2002; De Varennes, Melo-Abreu, and Ferreira 2002; Moujiri and Arzani 2003; Sadras 2006; Bakht et al. 2010; Hafiz et al. 2013).

\section{Conclusions}

Crops of Amaranthus cruentus cv Mexicano sowing in early december grown under irrigation and in a temperate, semiarid climate show an appropriate development of plants in their different phenologic stages and obtain hight economic yield respect to the genotypes Dorado and Antorcha.

Amaranthus cruentus cv Mexicano responded positively to nitrogenous fertilization. The increase in economic yield with progressively higher $\mathrm{N}$ fertilizer doses was mostly due to increments in the number of grains per panicle, and to the weight of 1000 grains to a lesser extent. Nitrogen enrichment also reduced the incidence of a fungal disease, augmented plant density per hectare, and enhanced various morphological parameters such as plant height, panicle length, stem diameter, and number of leaves, nodes, and ramifications. In addition, it augmented the crude-protein content of grains, and of other plant parts. Increases of these variables directly affected the augmentations observed in the dry weights of the stem, panicle and leaves.

Finally, the increase of the length of the growing cycle with an increased nitrogeneous-fertilization needs to be considered within the context of the difficulties found during harvesting and postharvesting managements in the north of Patagonia. 


\section{Acknowledgements}

The authors thank the Universidad Nacional de Santa Rosa for having donated the genetic material used in the assay; the Estación Experimental Agropecuaria Valle Inferior del Río Negro for the possibility to conduct this study; the Universidad Nacional de Río Negro, the Universidad Nacional del Sur, and CONICET for technical and professional support. Dr. Donald F. Haggerty, a retired career investigator and native English speaker, translated the original manuscript from Spanish into English and for Drs. Juan Martín Traverso, Marta Zubillaga y Mercedes Zubillaga for edited this work its final English version.

\section{Funding}

This work was partially funded by FITR-03/2013.

\section{References}

Agamennoni, R. 1995. Informe anual del plan de trabajo: Tecnología de la producción de cultivos semi intensivos alternativos. EEA INTA Hilario Ascasubi.

Ainika, J. N., B. M. Auwalu, and A. U. Yusuf. 2011. Response of grain amaranth to nitrogen and farm yard manure rates in Northern Guinea and Sudan savanna ecological zones of Nigeria. World Journal of Engineering and Pure and Applied Sciences 1 (2):46-9.

Alonge, S. O., F. O. Alonge, S. P. Bako, J. D. Olarewaju, and O. B. Adeniji. 2007. Effects of rates and split application of compound NPK fertilizer on the growth and yield of three Amaranthus species in Nigeria Guinea Savanna. Asian Journal of Plant Sciences 6 (1):906-12. doi: 10.3923/ajps.2007.906.912.

Arellano Vázquez, J. L., and J. A. Galicia Franco. 2007. Yield and plant and panicle traits in amaranth in response to nitrogen and seeding rate. Agricultura Técnica en México 33 (3):251-8.

Aufhammer, W., E. Kubler, and J. H. Lee. 1999. Grain quality of the pseudocereals buckwheat (Fagopyrum esculentum Moench), quinoa (Chenopodium quinoa Willd) and amaranth (Amaranthus hypochondriacus L. A. hybridus L.) in relation to growing conditions. Bodenkultur 50 (1):11-24.

Bavec, F., and S. G. Mlakar. 2002. Effects of soil and climatic conditions on emergence of grain amaranths. European Journal of Agronomy 17 (2):93-103. doi: 10.1016/S1161-0301(01)00144-7.

Bakht, J., M. Shafi, M. Yousaf, and H. U. Shah. 2010. Physiology, phenology and yield of sunflower (autumn) as affected by NPK fertilizer and hybrids. Pakistan Journal of Botany 42 (3):1909-22.

Barba De La Rosa, A. P., J. Gueguen, O. Paredes Lopez, and G. Viroben. 1992. Fractionation procedures electrophoretic characterization, an amino acid composition of amaranth seed proteins. Journal of Agricultural and Food Chemistry 40 (6):931-6. doi: 10.1021/jf00018a002.

Barba De La Rosa, A. P., C. Silva-Samchez, and E. González De Mejia. 2007. Amaranth: An ancient crop for modern technology. In Hispanic foods: Chemistry and flavor, eds. M. H. Tunick and E. Gonzalez De Mejia, $103-116$. Washington DC: American Chemical Society.

Barros, J. F. C., M. y Carvalho, and G. Basch. 2004. Response of sunflower (Helianthus annuus L.) to sowing date and plant density zunder mediterranean conditions. European Journal Agronomy 21 (3):347-56. doi: 10.1016/ j.eja.2003.10.005.

Bazzaz, F. A., and D. Ackerly. 1992. Reproductive allocation and reproductive effort in plants. In Seeds: The ecology of regeneration in plant communities, ed. M. Fenner, 1-26. Wallingford, UK: CAB International.

Bejosano, F., and H. Corke. 1998. Protein quality evaluation of amaranthus wholemeal flours and protein concentrates. Journal of the Science of Food and Agriculture 76 (1):100-6. doi: 10.1002/(SICI)1097-0010(199801)76: $1<100:$ :AID-JSFA931>3.0.CO;2-B.

Bélanger, G., J. R., Walsh, J. E. Richards, P. H. Milburn, and N. Ziadi. 2000. Comparison of three statistical models describing potato yield response to nitrogen fertilizer contribution 665 agriculture and agri-food Canada. Agronomy Journal 92 (5):902-8. doi: 10.2134/agronj2000.925902x.

Boote, K. J., J. M. Bennet, T. R. Sinclair, and G. M. Paulsen. 1994. Physiology and determination of crop yield, 601. Madison, WI: American Society of Agronomy, University of Minnesota. ISBN: 0-89118-122-9.

De Varennes, A., J. P. Melo-Abreu, and M. E. Ferreira. 2002. Predicting the concentration and uptake of nitrogen, phosphorus and potassium by field grown green beans under non-limiting conditions. European Society for Agronomy 17 (1):63-72. doi: 10.1016/S1161-0301(01)00138-1.

Di Rienzo, J. A., F. Casanoves, M. G. Balzarini, L. Gonzalez, M. Tablada, and C. W. Robledo. 2008. InfoStat, version 2008. Grupo InfoStat, FCA, Universidad Nacional de Córdoba, Argentina.

Diaz Ortega, A. C., J. A. Escalante Estrada, A. Trinidad Santos, P. Sánchez García, C. Mapes Sánchez, and D. Martinez Moreno. 2004. Rendimiento, eficiencia agronómica del ntrógeno y eficiencia en el uso del agua en amaranto en función del manejo del cultivo. Terra Latinoamericana 22 (1):109-16. 
Elbehri, A., D. H. Putnam, and M. Schmitt. 1993. Nitrogen fertilizer and cultivar effects on yield and nitrogen-use efficiency of grain amaranth. Agronomy Journal 85 (1):120-8. doi: 10.2134/agronj1993.00021962008500010023x.

Espitia, E. 1992. Informe de avances en la investigación en amaranto. Secretaría de agricultura y recursos Hidráulicos-Instituto nacional de investigaciones forestales, Agrícolas y pecuarias. Chapingo, México. p 76

FAO. 1993. Mujica-Sanchez, A., J. Izquierdo, and S. E. Jacobsen. Prueba americana de cultivares de amaranto. Reunión Técnica Y Taller de Formulación de Proyecto Regional Sobre Producción y Nutrición Humana en Base a Cultivos Andinos. p 47.

Gallagher, E., T. R. Gormley, and E. K. Arendt. 2004. Recent advances in the formulation of gluten-free cerealbased products. Trends in Food Science and Technology 15 (3-4):143-52. doi: 10.1016/j.tifs.2003.09.012.

Gimplinger, D. M., G. Dobos, R. Schönlechner, and H.-P. Kaul. 2007. Yield and quality of grain amaranth (Amaranthus sp.) in Eastern Austria. Plant, Soil and Environment 53 (3):105-12. doi: 10.17221/2224-PSE.

Gimplinger, D. M., G. Schulte auf'm Erley, G. Dobos, and H.-P. Kaul. 2008. Optimum crop densities for potential yield and harvestable yield of grain amaranth are conflicting. European Journal Agronomy 28 (2):119-25. doi: 10.1016/j.eja.2007.05.007.

Gunda, S. E., P. K. Hans, K. Markus, and A. Walter. 2005. Yield and nitrogen utilization efficiency of the pseudocereals amaranth, quinoa, and buckwheat under differing nitrogen fertilization. European Journal of Agronomy 22 (1):95-100.

Hafiz, M. H., A. Ashfaq, F. Wajid, A. Farhat, Q. Khalifa, and S. Shafqat. 2013. Nitrogen stimulates phenological traits, growth and growing degree days of maize. Pakistan Journal of Agricultural Sciences 50 (3):337-44.

Henderson, T. L. 1993. Agronomic evaluation of grain amaranth in North Dakota. Ph.D. thesis, North Dakota State, North Dakota.

Khandaker, L., A. S. M. G. Masum, and S. O. Akond. 2009. Air temperature and sunlight intensity of different growing period affects the biomass, leaf color and betacyanin pigment accumulations in red amaranth (Amaranthus tricolor L.). Journal of Central European Agriculture 10 (4):439-48.

Kigel, J. 1994. Development and ecophysiology of amaranths. In Amaranth biology, chemistry, and technology, ed. O. Paredez-López, 39-73. Boca Raton, FL: CRC Press.

Kho, R. M. 2000. On crop production and the balance of available resources. Agriculture, Ecosystem \& Environment 80 (1-2):71-85. doi: 10.1016/S0167-8809(00)00135-3.

Lehmann, J. W. 1990. The potential of grain amaranths in the 1990s and beyond. Proceedings of 4 th National Amaranth Symposium: Perspectives on Production, Processing, and Marketing. Minneapolis, MN. University of Minnesota, St. Paul, MN. pp. 1-7.

Lezcano, E. 2013. Cadena quinoa y amaranto. Ministerio de agricultura, Alimentos argentinos, Dirección de agroalimentos, Área de sectores alimentarios. Buenos Aires, Argentina. www.alimentosargentinos.gob.ar.

Makus, D. J. 1990. Applied N affects vegetable and seed quality. Proceedings of 4th National Amaranth Symposium: Perspectives on Production, Processing and Marketing. Minneapolis, MN. University of Minnesota, St. Paul, MN. pp. 187-188.

Mapes, S. E. C., and E. R. Espitia. 2010. Recopilación y análisis de la información existente de las especies del género Amaranthus cultivadas y de sus posibles parientes silvestres en méxico. IB-UNAM, INIFAP-CE Bajío. p. 242.

McMaster, G. S., and W. W. Wilhelm. 1997. Growing degree-days: one equation, two interpretations. Agricultural and Forest Meteorology 87 (4):291-300. doi: 10.1016/S0168-1923(97)00027-0.

Moujiri, A., and A. Arzani. 2003. Effects of nitrogen rate and plant density on yield and yield components of sunflower. Journal of Science and Technology of Agriculture and Natural Resources 7 (2):115-25.

Mujica, A., M. Berti, and J. Izquierdo. 1997. El cultivo de amaranto (Amaranthus sp.): Producción, mejoramiento genético y utilización. Departamento de Agricultura, División de Producción y Protección Vegetal, Roma, Italia. p. 97.

Myers, R. L. 1998. Nitrogen fertilizer effect on grain amaranth. Agronomy Journal 90 (5):597-602. doi: 10.2134/ agronj1998.00021962009000050005x.

Olaniyi, J. O., K. A. Adelasoye, and C. O. Jegede. 2008. Influence of nitrogen fertilizar on the growth, yield and quality of grain amaranth varieties. Word Journal of Agricultural Science 4 (4):506-13.

O'Brien, G. K., and M. L. Price. 2008. Amaranth grain and vegetable types. ECHO Technical Note. www.echonet.org.

Pedroza, R. I. 1989. Efecto de la fecha de siembra en cinco variedades de amaranto (Amaranthus spp.). Tesis Profesional Z.A., UACh, Chapingo, México. p. 81.

Peterka, J., B. Vozrenilková, J. Moudr, and L. Illés. 2001. Growing of amaranth and its importance in mans nourishment. Acta Fytotechnica et Zootechnica 4 (1):212-3.

Pospisil, A., M. Pospisil, B. Varga, and Z. Svecnjak. 2006. Grain yield and protein concentration of two amaranth species (Amaranthus spp.) as influenced by the nitrogen fertilization. European Journal Agronomy 25 (3):250-3. doi: 10.1016/j.eja.2006.06.001.

Prasad, P. V. V., V. Satyanarayana, V. R. K. Murthy, and K. J. Boote. 2002. Maximizing yields in riceground cropping sequence through integrated nutrient management. Field Crop Research 75 (1):9-21. doi: 10.1016/S03784290(01)00214-3. 
Putnam, D. H. 1990. Agronomic practices for grain amaranth. Proceedings of 4th National Amaranth Symposium. Minnesota Ext. Serv. University of Minnesota, St Paul, MN. pp. 151-162.

Randy, W. 1991. Soybean growth response to plant density: Relationships among canopy photosynthesis, Leaf area, and light interception. Crop Science 31 (3):755-61.

Reekie, E. G. 1998. An explanation for size-dependent reproductive allocation in plantago major. Canadian Journal of Botany 76 (1):43-50. doi: 10.1139/b97-160.

Reinaudi, N. B., Repollo, D. Janovská, J. Délamo Frier, R. Martín de Troiani. and R. 2011. Evaluación de genotipos de amaranto (Amaranthus spp.) Para la adaptabilidad productiva en el área de la facultad de agronomía, Universidad nacional de La Pampa. Revista Científica UDO Agrícola 11 (1):50-7.

Troiani, R. M., T. M. Sánchez, and N. B. Reinaudi. 2004. Optimal sowing dates of three species of grain-bearing amaranth in the semi-arid argentine pampa. Spanish Journal of Agricultural Research 2 (3):385-91. doi: 10.5424/ sjar/2004023-93.

Sadras, V. O. 2006. The N: P stiochiometry of cereal, grain legume and oilseed crops. Field Crop Researach 95 (1): 13-29. doi: 10.1016/j.fcr.2005.01.020.

Sanchez, E. M. C., R. E. Espitia, and S. Osada Kawasoe. 1991. Etiología de la mancha negra del tallo (Macrophoma sp.) en Amaranto (Amaranthus spp.). Primer Congreso Internacional del Amaranto September 22-27, 1991. Oaxtepec, Morelos, México. p. 67.

Schulte, G., H. P. Kaul, M. Kruse, and W. Aufhammer. 2005. Yield and nitrogen utilization efficiency of the pseudocereals amaranth, quinoa, and buckwheat under differing nitrogen fertilization. European Journal Agronomy 22 (1):95-100. doi: 10.1016/j.eja.2003.11.002.

Segura Nieto, M., A. P. Barba de la Rosa, and O. Paredes López. 1994. Biochemistry of amaranth proteins. In Amaranth biology, chemistry and technology, ed. O. Paredes-López, 75-106. Boca Raton, FL: CRC Press.

Stallknecht, G. F., and J. R. Schulz-Schaeffer. 1993. Amaranth rediscovered. In New crops, eds. J. Janick and J. E. Simon, 211-218. New York, NY: Wiley.

Vargas López, J. L., G. Covas, and F. J. Bailac. 1993. Comportamiento de ocho cultivares de amaranto granifero (Amaranthus spp.) anguil, Prov. de La Pampa. Campaña 1991/1992. Boletín Informativo INTA. p. 7.

Welham, C. V. J., and R. A. Setter. 1998. Comparison of size-dependent reproductive effort in two dandelion (Taraxacum officinale) populations. Canadian Journal of Botany 76 (1):166-73. doi: 10.1139/b97-176.

Whitehead, W. F., J. Carter, and B. P. Singh. 2002. Effect of planting date on vegetable amaranth leaf yield, plant height, and gas exchange. HortScience 37 (5):773-7.

Williams, J. T., and D. Brenner. 1995. Grain amaranth (Amaranthus species). In Cereals and pseudocereals, ed. J. T. Williams, 129-186. London, UK: Chapman and Hall.

Wu, H., M. Sun, S. Yue, H. Sun, Y. Cai, R. Huang, D. Brenner, and H. Corke. 2000. Field evaluation of an amaranthus genetic resource collection in China. Genetic Resources and Crop Evolution 47 (1):43-5. doi: 10.1023/A: 1008771103826.

Yarnia, M. 2010. Sowing dates and density evaluation of amaranth (Cv. Koniz) as a new crop. Advances in Environmental Biology 4 (1):41-6.

Žajová, A., L. Koštál, and M. Vereščák. 2001. An unconventional crop - Amarant (Amaranthus). In Acta fytotechnica et zootechnica, ed. Magdaléna Lacko-Bartošová. Proceedings of the International Scientific Conference on the Occasion of the 55th Anniversary of the Slovak Agricultural University of Nitra, 4 (1):216-217 (Special issue).

Zhang, D., L. Zhang, J. Liu, S. Han, Q. Wang, J. Evers, J. Liu, W. van der Werf, and L. Li. 2014. Plant density affects light interception and yield in cotton grown as companion crop in young jujube plantations. Field Crops Research 169:132-9. doi: 10.1016/j.fcr.2014.09.001.

Zheleznov, A. V., L. P. Solonenko, and N. B. Zheleznova. 1997. Seed proteins of the wild and the cultivated Amaranthus species. Euphytica 97 (2):177-82. 